\title{
Student-Centered Support Systems to Sustain Logo-Like Learning
}

\author{
Sylvia MARTINEZ \\ Generation YES, Olympia \\ 2584 RW Johnson Blvd. SW, Olympia, Washington, USA \\ e-mail: sylvia@genyes.com
}

Received: August 2007

\begin{abstract}
Conventional wisdom attributes the lack of effective technology use in classrooms to a shortage of professional development or poorly run professional development. At the same time, logo-like learning environments require teachers to develop more expertise not only in technology but also in pedagogy.

This paper proposes that the perceived lack of technology professional development is a myth and that traditional professional development is ill-suited to teaching teachers how to create logolike learning environments. Furthermore, it proposes models of student-centered, student-led support for teachers that support classroom practice aligned with the attributes of logo-like learning environments. These models situate teacher learning about technology in their own classroom, reinforce constructivist teaching practices, provide support for technology use in the classroom, and enrich learning environments for students.
\end{abstract}

Key words: student-centered, logo-like, technology, professional development, learning environment.

\section{Problems in Professional Development for Logo-Like Learning}

Logo-like learning is characterized by learning by doing, experimentation, authentic work, student agency, serendipity, reflection, collaboration, and community expertise. It requires teachers with intellectual curiosity, creativity, ongoing personal learning habits, and the ability to collaborate with students while maintaining a classroom that has both purpose and freedom. Such teachers are able to create learning environments that are distinguished by intellectual challenge, wonder, social interaction, and student engagement (Harvey, 1993; Papert, 1992; Stager, 2005).

Although technology enables logo-like learning, it requires substantially more technical and intellectual fluency from a teacher than the typical computer application courses found in many schools. This makes the professional development challenges more substantial.

Regardless of its merits, logo-like learning has proven difficult to sustain in traditional schools. While Papert attributes this to school's "immune reaction" to an invading foreign body (Papert, 1997), conventional wisdom ascribes this failure to lack of teacher professional development. 


\section{The Myth of Insufficient Professional Development}

The speculation that the primary barrier to effective technology use in schools is the result of insufficient professional development goes unquestioned and has become a myth used to excuse the lack of progress.

Lack of professional development for technology use is one of the most serious obstacles to fully integrating technology into the curriculum (Fatemi, 1999; Office of Technology Assessment, 1995; Panel on Educational Technology, 1997) (Rodriguez and Knuth, 2000).

Even when the style of professional development is called into question, the typical remedy is more of the same, with additional structure and more emphasis on external expertise.

But traditional sit-and-get training sessions or one-time-only workshops have not been effective in making teachers comfortable with using technology or adept at integrating it into their lesson plans. Instead, a well-planned, ongoing professional development program that is tied to the school's curriculum goals, designed with built-in evaluation, and sustained by adequate financial and staff support is essential if teachers are to use technology appropriately to promote learning for all students in the classroom (Rodriguez and Knuth, 2000).

Critiques from a wide spectrum of researchers focus on variables such as evaluation, seat time, correlation to mandated curriculum standards, testing outcomes, and compensation. Occasionally, issues of teachers' motivation to learn are mentioned (Brand, 1997; Rodriguez and Knuth, 2000).

The truth is, American (and most Western) teachers are receiving quite a bit of professional development related to technology.

Indeed, most teachers had participated in multiple professional development activities in the year prior to taking the survey, and yet more than 80 percent indicated a need for training in how to integrate technology into the curriculum (SRI, 2002).

Most teachers indicated that professional development activities were available to them on a number of topics, including the use of computers and basic computer training, training on software applications, and the use of the Internet (ranging from 96 percent to 87 percent). Among teachers reporting these activities available, participation was relatively high (ranging from 83 to 75 percent), with more experienced teachers generally more likely to participate than less experienced teachers (NCES, 2000).

In a 2003 study of teachers in the Chicago Public Schools, a large majority of teachers confirmed that lack of professional development was not a great barrier to technology use (CCSR, 2003) (Fig. 1).

\section{Failure of Traditional Professional Development}

The failure of traditional professional development to change teacher practice with technology may be due to several factors. Effective use of technology, such as those sought in 


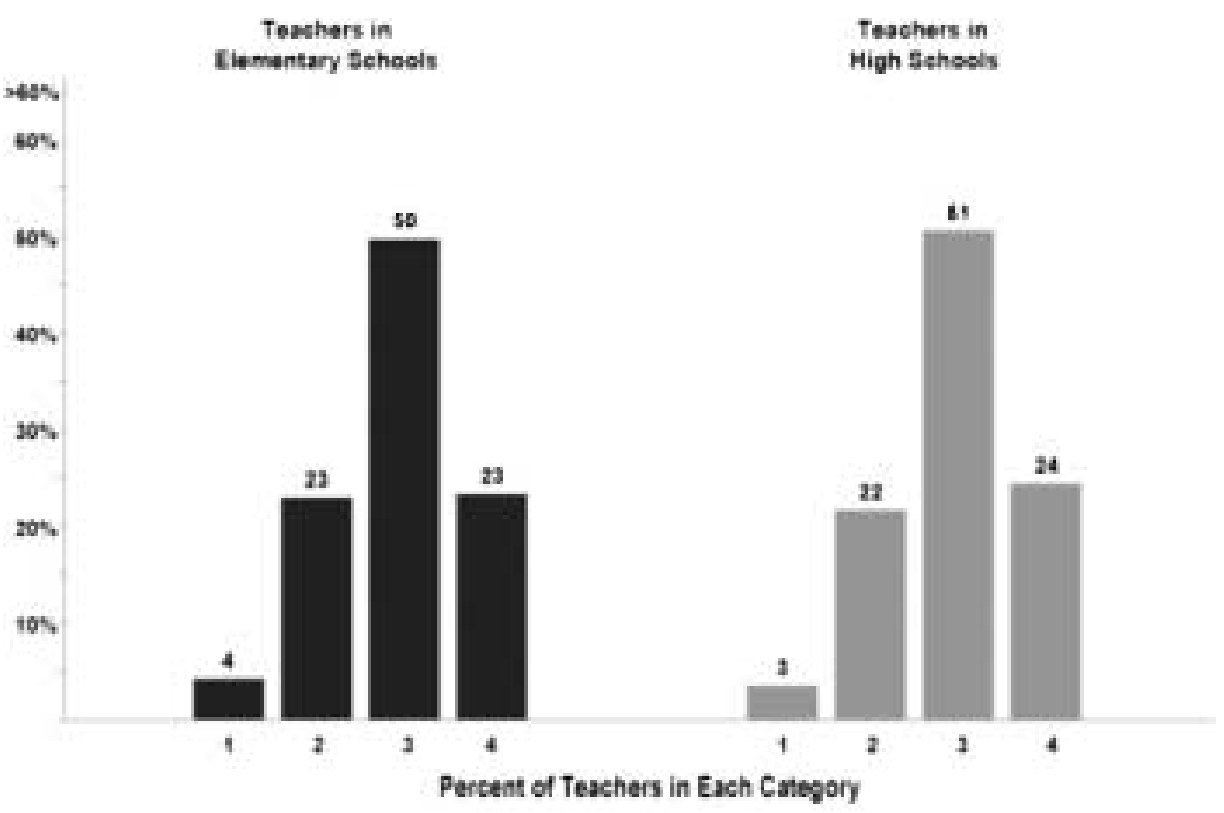

Fig. 1. Teachers' assessments of their awareness of and participation in professional development activities designed to integrate technology in the classroom.

Definition of Categories Charted Above

\begin{tabular}{|c|c|}
\hline Category & In Chicago Public Schools: \\
\hline 1 - Very Weak & $\begin{array}{l}\text { Teachers agree that the lack of both appropriate professional development and } \\
\text { release time for learning and planning are great barriers to technology use. }\end{array}$ \\
\hline 2 - Weak & $\begin{array}{l}\text { Teachers somewhat agree that lack of both professional development and release } \\
\text { time to be great barriers to technology use. }\end{array}$ \\
\hline 3 - Strong & $\begin{array}{l}\text { Teachers find lack of both professional development and release time as small } \\
\text { barriers to moderate barriers. }\end{array}$ \\
\hline 4 - Very Strong & $\begin{array}{l}\text { Teachers describe the lack of professional development and release time as not a } \\
\text { barrier. }\end{array}$ \\
\hline
\end{tabular}

a logo-like learning environment, extends well beyond understanding the specific technology. It requires a different teaching style. Traditional approaches to professional development tend towards the didactic, while the real power of the computer is when it's used in a personally meaningful, constructive fashion.

Federal, state and local agencies are investing billions to equip schools with computers and modern communication networks, but only one-third of our nation's teachers feel well prepared to use computers and the Internet in their teaching (NCES, 2000).

This is evident in reports by students of computer use in their classes. In the 2005/06 school year, thousands of GenYES students in the United States were asked about their own computer use. This is astonishing, considering that GenYES schools are a self- 
selected group with a deliberate intent to improve the use of technology in every classroom. These results have not changed significantly in five previous annual surveys.

\begin{tabular}{lccccc}
\hline $\begin{array}{l}\text { In the classes you took last } \\
\text { semester/quarter, how often were } \\
\text { computers used by you or your } \\
\text { teachers? }\end{array}$ & $\begin{array}{c}\text { Computers } \\
\text { were never } \\
\text { used }\end{array}$ & $\begin{array}{c}\text { Computers } \\
\text { were used } \\
\text { once }\end{array}$ & $\begin{array}{c}\text { Computers } \\
\text { were used } \\
\text { a few times }\end{array}$ & $\begin{array}{c}\text { Computers } \\
\text { were used } \\
\text { about once } \\
\text { per week }\end{array}$ & $\begin{array}{c}\text { Computers } \\
\text { were used } \\
\text { several } \\
\text { times per } \\
\text { week }\end{array}$ \\
\hline Math & $46.5 \%$ & $9.4 \%$ & $26.1 \%$ & $8 \%$ & $9.9 \%$ \\
Language Arts, Reading or English & $30.4 \%$ & $11.2 \%$ & $33.6 \%$ & $12.2 \%$ & $12.7 \%$ \\
Science & $47.2 \%$ & $13.2 \%$ & $25.4 \%$ & $6.7 \%$ & $7.4 \%$ \\
Social Studies, Geography or History & $36.8 \%$ & $12.2 \%$ & $27.8 \%$ & $11 \%$ & $12.3 \%$ \\
\hline
\end{tabular}

In the same time period, the number of computers available for classroom use in the U.S. went from approximately one computer for every six students to one to every four students (SAUS, 2006). Even if the pace of computer introduction has slowed from the rapid changes of the 1980s and 1990s, there is certainly sufficient availability. There should be significantly more use of computers in the daily lives of students.

Despite the evidence that traditional professional development is ineffective, there remains an insatiable appetite for more. Perhaps the important variable isn't quantity, but constancy and community.

\section{Community of Practice}

The primary community of practice for teachers is within the confines of their own classroom. The participants are the teacher and her students. Other peripheral participants can visit, but for most classrooms, these visits are few and short. While teachers may participate in other communities in a professional capacity, for most, the classroom is the only setting for their professional practice.

Wenger, in discussing designs for learning inside communities of practice, makes the point that they, “... cannot be based on a division of labor between learners and nonlearners, between those who organize learning and those who realize it, or between those who create meaning and those who execute" (Wenger, 1998).

Traditional forms of professional development remove the teacher from their classroom and attempt to create a community of practice made up of teachers and technology experts. This community exists only for the purpose of imparting information from the experts to the teachers. While there is certainly a place for collegial discussion and access to professional improvement, it is not unreasonable that teachers often reject transparent efforts to force them into participation.

Common recommendations for technology professional development include that teachers be given more time for "independent practice without fear of embarrassment", to watch expert practitioners, go to conferences and workshops, or participate in online learning communities (Rodriguez and Knuth, 2000). 
These attempts to improve technology professional development only serve to reinforce the separation between the teacher learning new skills and real change in classroom practice. Schlager \& Fusco construct a compelling argument based on years of design and facilitation of Tappped-In, an online teacher community. This type of professional development, “... tends to pull professionals away from their practice, focusing on information about a practice rather than on how to put that knowledge into practice" (Schlager and Fusco, 2004).

Mere discussion about practice does not create a community of practice.

Even if professional development excites teachers about new possibilities and tools, the teachers are removed from the successful context and sent back to the classroom to fend for themselves. They are expected to use their new skills without colleagues or experts present. One-on-one coaching that provides in-class mentoring is expensive and rarely available. Online teacher communities can only take place outside of classroom time, too late for any intervention or advice to be useful. As teachers struggle alone in their classroom with questions, issues, and problems, valuable teachable moments are missed.

In an interview discussing what changes need to take place in classrooms to allow project-based learning, Papert says, "What we need is kinds of activity in the classroom where the teacher is learning at the same time as the kids and with the kids. Unless you do that, you'll never get out of the bind of what the teachers can do is limited by what they were taught to do when they went to school" (Papert, 2001).

Creating sustainable systems that allow teachers to learn alongside students in the classroom is imperative to support teachers responsible for sustaining logo-like learning.

\section{The GenYES Model}

GenYES is a model of reverse mentoring developed specifically for K-12 teachers learning to use computers in their classrooms. GenYES students learn about technology, develop planning and collaboration skills, and learn how people learn. As a culminating project, each student is partnered with a teacher in the school. These student/teacher teams review the teacher's curriculum and decide on a future lesson that could be enhanced with technology. The student then researches and creates the project, with the teacher providing insight into pedagogy and the curricular content. When the project is completed, the teacher has something they can use in their classroom, understands of technology better and can directly observe the impact on their students (Harper, 1998).

A single teacher or staff member facilitates all of this as the GenYES teacher. A decade of research demonstrates that this model improves teachers' use of technology in the classroom and changes teacher attitudes about the usefulness of technology as they view the benefit to their students (Coe, 2003; Harper, 1998). Over the last 10 years, the model has been called Gen Y or Generation www.Y, but is now known as GenYES

"The format provides a model of project-based, authentic, student-centered, multidisciplinary teaching and learning enhanced by technology" (Coe, 2003). 
This partnership creates a two-person collaborative learning community grounded in constructivist pedagogy. Both the student and the teacher are bringing important skills and knowledge to the partnership. Improving technology use in schools is an authentic problem worth solving. Working together creates mutual respect and understanding about each other's roles.

The model facilitates a constructivist atmosphere in the whole school, not by teaching teachers how to teach, but by giving students an authentic problem to solve and asking teachers to help. GenYES builds on the pedagogical models developed by Dr. Papert and the years of research about what constructivist teachers do in classrooms.

Teachers working with GenYES students report that the experience helped them better understand technology and its place in education.

- $89 \%$ agreed that as a consequence of GenYES, their students learned content better.

- $98 \%$ reported that as a consequence of GenYES, they would continue rebuilding their lessons to make more use of technology.

- $82 \%$ reported that the GenYES experience would change the way they teach in the future.

- $95 \%$ of the partner-teachers consider GenYES a good method for providing support and assistance to teachers as they integrate technology into their classes, (Coe, 2003).

\section{Constancy and Community}

Although the GenYES model is a structured mentoring process with a specific focus, it sheds light on the steps and key factors needed to create a classroom community of practice that supports logo-like learning.

In the classic explanation of social constructionism, Papert describes the Brazilian samba school where, "Novice is not separated from expert, and the experts are also learning" (Papert, 1980).

By creating a classroom-based learning community like GenYES, the problems of constancy and community are solved. Teachers and students can be teachers, learners, novices or experts. Roles can shift from day to day, task to task. Teachers can try new technology knowing that their students have expertise, or if not, the class can learn it together. Together, they are doing the real work of learning. This community of practice is available all the time and not dependent on outside expertise.

There is of course a role for outside expertise, but accessing an outside expert and sharing it with a community allows the whole community to benefit. Modelling that behavior for students creates an expectation that learning to learn is the key to success.

\section{Creating and Sustaining Classroom Practice that Supports Logo-Like Learning}

Even if student-led models of support like GenYES are initiated in a school, the question remains, how will teachers know what to do and how will teachers and students learn how 
to use technology? Surely, they will need textbooks, lesson plans, curriculum, experts, and reference material?

While there is certainly a need for reference material, there is ample evidence that when students and teachers work together to solve authentic problems, their search for the solution, and their ownership of the process creates a deeper understanding than a pre-planned lesson. In the age of the Internet, fixed lesson plans become less important as resources change rapidly, and search engines bring answers immediately when questions come up. The answer to "how do I ..." is easy to find. Having an authentic reason to ask that question is hard. This should be the focus of the teacher's role in creating a logo-like learning environment.

In an interview about the One Laptop Per Child Initiative, Papert responds to the question, how will teachers and students be trained, with, "In the end, they will teach themselves. They'll teach one another. There are many millions, tens of millions of people in the world who bought computers and learned how to use them without anybody teaching them. I have confidence in kids' ability to learn" (Papert, 2006).

During the professional development process for the GenYES lead teacher, no technology instruction occurs. GenYES lead teachers are encouraged to teach collaboration and communication skills to their students. Lesson plans and role-playing scripts for the students are provided since most have little experience working collegially with an adult. Our lead teachers are encouraged to have students work on projects as quickly as possible and provide sufficient time and space necessary to create an atmosphere that rewards risk-taking.

\section{Getting Out of the Way}

One of the most common comments from beginning GenYES teachers is that they saw the class start to work when they "got out of the way". Although the value of student self-reliance is stressed in the GenYES teacher resource materials and professional development activities, many teachers need to see students assume responsibility for their own learning to be convinced. Some teachers experience an epiphany when they suddenly realize the creative chaos in their classroom is not only functional, but valuable. They then allow themselves to surrender some control. This tendency for technology projects to follow many varied paths can in and of itself be the catalyst that forces teachers to step out of their leadership role in the classroom.

\section{Fear of Failure}

Fear of failure, of looking stupid, and of losing control also play a large part in whether a teacher can create an environment that allows students to take the lead. Teachers often create carefully staged lessons in technology based on their own fear of the computer, rather than a true understanding of what students need to know. By creating a delay in the process of students getting to the real work, teachers assuage their own fears, but bore students. Recommendations that teachers practice new technology skills in private only serve to intensify this fear by acknowledging that mistakes are shameful and will somehow harm students. 
Technology Choice, Implementation, and Support as an Authentic Problem

Authentic problems inspire creative thinking and empower students to exceed expectations and think creatively. Technology in education has many authentic problems beyond the use in the classroom. Selecting the right tools, creating acceptable use provisions and penalties, making decisions about security, analyzing costs, and planning for maintenance are all considerations.

Teachers can sometimes act as roadblocks in technology use as their quest to find the perfect technical solution and design a flawless implementation plan takes months or even years to complete. Students can shortcut this process and learn valuable lessons along the way.

By including students in the process of researching, choosing, testing, and implementing new technology, students experience not just the use of technology, but the decisionmaking process and tradeoffs that surround it. By including them in making and enforcing safety or usage policies, they are learning to think beyond their own experiences, make predictions, and take responsibility for community actions. Students who participate in these tasks will communicate and explain policies to their peers more effectively than adults. Students will also be more forgiving of technology shortcomings that inevitably takes place when implementing new technology if they have been a part of the discussion of tradeoffs.

Papert makes the case for student's leading the way to creating their own learning environments, "I believe in "Kid Power". Our education systems underestimate kids. It INFANTALIZES them by assuming they are incompetent" (Papert, 2006).

Of course, there are times when a teacher introduces an application or technology that supports specific curricular or pedagogical goals. The process of including the students in authentic problems does not mean that students need to be included in every aspect of the process.

\section{Students as Teachers}

To teach is to learn twice - Joseph Joubert

It is not unusual for students to serve in the role of teachers in schools, although these are usually near-age peer tutoring programs. In technology settings, the research done on children as software designers (Harel, 1991; Kafai, 1995) outlines multiple benefits of students collaborating and teaching each other as they design educational software and games. However, there are ways that students can teach peers, teachers, and other members of their community about technology that benefit the entire school. By creating a legitimate role for students of this digital generation to share their experience and facility with technology, schools can create in-class professional development opportunities for teachers, support teachers as they use technology in the classroom, and provide better technical support to teachers in the classroom.

This does not mean that students can just be told to help out and this will automatically have a significant impact. The success of the GenYES model shows that these students need guidance to learn new roles and be successful collaborators and teachers. Teachers and staff need guidance as well and time to learn to trust and accept new roles for students. 


\section{Students as Teachers of Teachers}

In the GenYES model, students serve as teachers in one-on-one partnerships with teachers. The model supports both students and teachers as co-learners and co-teachers. Building on a time honoured practice of students "helping out" GenYES is a non-threatening, yet subtly subversive way to have students contribute to the technology-enabled learning environment.

Papert said about the GenYES model, "The genius of this idea is that by contributing to solving a recognized problem facing schools, it rallies support from schools for something that goes against the grain of their traditional ways of thinking" (Papert, 1998).

Our research indicates that teachers are not embarrassed by students teaching them about technology. Teachers became teachers because they like children. The key is creating a school-wide environment where the teacher and student interaction and knowledge sharing is a normal and accepted practice.

\section{Students as Teachers of Peers}

Student peer mentoring can also serve as a primary support system for logo-like learning environments. Student mentors leverage student expertise and benefit both students and teacher. Peer mentors:

- Increase available opportunities for all students. Other students can get assistance more quickly and in more areas than if the classroom must rely on a single expert (the teacher) or wait for outside expertise.

- Allows the teacher to teach. The teacher is relieved of the role of sole technology guru and can focus on helping struggling students, focus on bigger ideas, and be attuned for teachable moments.

- Expand the capacity for multiple applications and hardware. Individual students can become expert in an application or a particular use of technology and help others.

Encouraging student expertise in technology mentoring also creates leadership opportunities for students that support their own personal interests and learning styles. They will learn these skills more deeply and with greater enthusiasm than a student asked to learn a little bit about a lot of applications. A spreadsheet expert can be as important and celebrated as a student with expertise in animation, 3D design or music composition. If these unique gifts and interests are recognized and honored in the classroom, teachers, students, and the mentors themselves benefit.

In addition, the social, academic, and behavioral benefits of peer mentoring for both the mentor and the mentee are well documented (Gartner and Riessman, 1993; Benard, 1990; Viadero, 2003). This is especially true in at-risk communities, where peer mentors can bridge cultural gaps between teachers and students (Snow, 2003; Rohrbeck, 2003).

We have formalized this model in a student technology literacy program called TechYES. Research on the TechYES model shows that teachers report increases in a wide array of student technology skills, as would be expected, but also report increases 
in student and mentor self-esteem, interpersonal skills and academic skills. In addition, teachers reported that this model increased their understanding and ability to teach in a project-based, open-ended way than prior to teaching the TechYES class (Schneider, 2006).

\section{Students as Technical Suport}

Another way students can serve as support for teachers using technology in the classroom is as technical support. This solution has many benefits for both teachers and students. Teachers with consistent access high-quality technology support use technology more with students, and in a wider variety of ways, than teachers with inadequate technology support programs (Ronnkvist et al., 2000).

Students benefit from the challenges and responsibility given to them. Students learn how to troubleshoot and find answers by researching them, not being told. The problems found in school computers are authentic, varied and the need is high. Students also work well with teachers, at least as well as hired technical support staff. Students' knowledge of the school, the culture, and the teachers helps them solve problems in ways that support the learning environment.

\section{Conclusion}

The only resource in abundance in schools is students and their boundless energy, passion and enthusiasm for learning. By creating structures in classrooms and schools that encourage and support student participation in creating logo-like learning environments, we improve teacher practice and diminish dependency on outside expertise for teacher professional development.

\section{References}

Benard, B. (1990). The Case for Peers. Northwest Regional Educational Laboratory, Portland, OR.

Brand, G. (1997). What research says: training teachers for using technology. Journal of Staff Development, 19(1). Retrieved April 2, 2007 from

http: / / www.nsdc.org/library/publications / jsd/brand191. c fm.

Coe, M.T. (2003). Students, Teachers, and Technology Building Better Schools: Generation Y Project Evaluation. Northwest Regional Educational Laboratory, Portland, OR.

Available: http://genyes .org/products/geny/genyresearch

Consortium on Chicago School Research (2003). Key Measures of School Development. Retrieved April 12, 2007 from

http: / / ccsr.uchicago.edu/web_reports/keymeasures/keymeasures.html,

Gartner, A., and F. Riessman (1993). Peer-Tutoring: Toward a New Model. ERIC Digest. ED362506.

Harel, I. (1991). Children Designers. Ablex, NJ.

Harper, D. (1998). Generation Y: Second Annual Report. U.S. Department of Education, Washington, DC.

Harvey, B. (1993). Symbolic programming vs. software engineering - fun vs. professionalism - are these the same question? In Eurologo1993. Retrieved April 10, 2007 from University of California, Berkleley website: http: / / www.cs.berkeley. edu/ bh/elogo.html

Kafai, Y. (1995). Minds In Play: Computer Game Design as a Context for Children's Learning. Erlbaum, NJ. 
National Center for Education Statistics (2000). Public School Teachers' Use of Computers and the Internet U. S. Department of Education, Washington, DC.

Papert, S. (1980). Mindstorms: Children, Computers and Powerful Ideas. Basic Books, Inc., New York.

Papert, S. (1992). The Children's Machine: Rethinking School in the Age of the Computer. Basic Books, Inc., New York.

Papert, S. (1997). Why school reform is impossible. The Journal of the Learning Sciences, 6(4), $417-427$. Retrieved April 12, 2007 from http: / / papert.org/articles/school_reform.html

Papert, S. (2001). Seymour Papert on Project-Based Learning. Edutopia: The George Lucas Educational Foundation. Retrieved April 10, 2007 from

http: / / www . edutopia.org/php/interview.php?id=Art_901\&key=037\#paragraph6

Papert, S. (1998). Technology in Schools: To Support the System or Render it Obsolete. Milken Family Foundation. Retrieved April 1, 2007 from

http: / / www.mff.org/edtech/article.taf?_function=detail\&Content_uid1=106

Papert, S. (2006). Professor Papert Discusses One Laptop Per Child Project. U.S. International Information Programs (USINFO) Webchat transcript. Retrieved April 14, 2007

http: //usinfo.state.gov/usinfo/Archive/2006/Nov/14-358060.html

Ronnkvist, A., S. Dexter and R. Anderson (2000). Technology Support: Its Depth, Breadth, and Impact in America's Schools. Center for Research on Information Technology and Organizations, University of California, Irvine And University of Minnesota. Retrieved April 10, 2007 from

http: / / www.crito.uci.edu/tlc/findings/technology-support/startpage.htm

Rodriguez, G., and R. Knuth (2000). Critical Issue: Providing Professional Development for Effective Technology Use. North Central Regional Technology in Education Consortium (NCRTEC). Retrieved April 12, 2007 http: / / www . ncrel .org/sdrs/areas/issues/methods/technlgy/te1000.htm

Rohrbeck, C.A., M.D. Ginsburg-Block, J.W. Fantuzzo and T.R. Miller (2003). Peer-assisted learning interventions with elementary school students: a meta-analytic review. Journal of Educational Psychology, 95(2), 240-257.

Schlager, M.S., and J. Fusco (2004). Teacher professional development, technology, and communities of practice: Are we putting the cart before the horse? In S. Barab, R. Kling and J. Gray (Eds.), Designing Virtual Communities in the Service of Learning. Cambridge University Press.

Schnieder, S. (2006). Verizon California Technology Literacy Project Interim Evaluation. Private evaluation study delivered to Verizon. Retrieved August 2006 from http: / /www.geny . org/verizon/ evaluation/TechYES_Interim_Evaluation_Report.pdf

Snow, D. (2003). Classroom Strategies for Helping at-Risk Students, Noteworthy Perspective. Mid-continent Research for Education and Learning, available from www . mcrel. org

Stager, G. (2005). Papertian constructionism and the design of productive contexts for learning. In Proceedings of EuroLogo 2005. Retrieved April 5, 2007 from

http: // eurologo2005.oeiizk.waw.pl/PDF/E2005Stager.pdf

Stanford Research Institute (2002). Integrated Studies Of Educational Technology: Professional Development And Teachers' Use Of Technology. Prepared for the U.S. Department of Education Policy and Program Studies Service.

Statistical abstract of the United States (2006). Data User Services Division, Bureau of the Census, Economics and Statistics Administration, U.S. Dept. of Commerce, Washington, DC. Retrieved April 10, 2007 from http: / /www. census.gov/compendia/statab/education/

Viadero, D. (2003). Studies Show Peer Mentoring Yields Benefits for Students. Retrieved July 9, 2003 from http: / / www . edweek.org/ew/articles/2003/07/09/42peer.h22 .html

Wenger E. (1998). Communities of Practice: Learning, Meaning, and Identity. Cambridge University Press, Cambridge. 
S. Martinez is the president of Generation YES, speaks and writes on student empowerment with technology, game and educational publishing, and authentic technology use in K-12 schools. Sylvia oversaw product development, design and programming as a publisher of game and educational software on PC, Internet and console platforms. Sylvia also designed several educational websites, including Math.com, the award-winning web site that provides math help to students worldwide. Sylvia was an executive producer at Davidson \& Associates/Knowledge Adventure, a leading educational software developer. She designed, developed and launched dozens of educational software products and games. Prior to joining the educational technology field, Martinez was a senior engineer at Magnavox Research Labs, where she developed high-frequency receiver systems and navigation software for GPS satellites. Sylvia has been a featured speaker at national education technology conferences in areas ranging from the use of the Internet in schools, Web 2.0 technologies, student leadership, project-based and inquiry-based learning with technology and gender issues in science, math, engineering and technology (STEM) education. She holds a master's in educational technology from Pepperdine University, and a bachelor's degree in electrical engineering from the University of California, Los Angeles.

\title{
Nukreiptos į studentą Logo kalba grindžiamos mokymosi sistemos
}

\author{
Sylvia MARTINEZ
}

Mokykloje yra stygius efektyviu technologiju bei profesinès pletros. Logo aplinkos iš mokytoju reikalauja didinti kompetencijas ne tik technologijoje, bet ir pedagogikoje. Šis straipsnis teigia, kad technologiju profesionalios plètros stoka yra mitas ir kad tradicine profesionali plètra yra netinkama mokyti mokytojus, kaip sukurti Logo mokymosi aplinkas. Be to, šis straipsnis pateikia i mokini nukreiptus ir mokiniui talkinančius modelius, kai norima paremti klasės pritaikymą Logo mokymosi aplinkai. Šie modeliai leidžia mokytojui mokytis technologijų savo klasèse, padeda jomis naudotis ir pagerina mokinių mokymosi aplinkas. 